Historic, archived document

Do not assume content reflects current scientific knowledge, policies, or practices. 



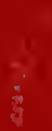

on 

(10) (10) (10) (10) (10) (10) (10) (10) (10) (10) (10) (10) (10) (10) (10) (15) (10) (10) (0) (10) (10

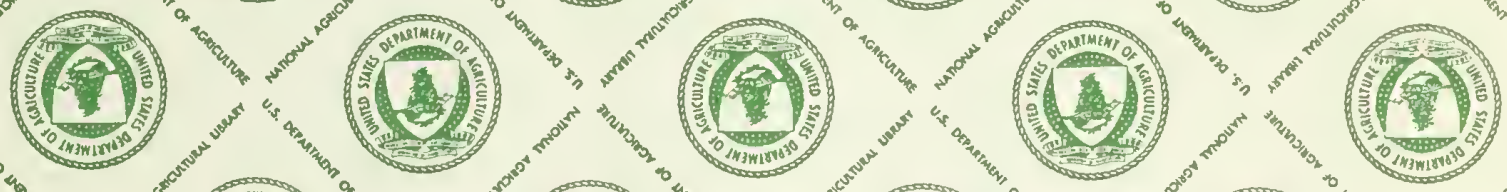

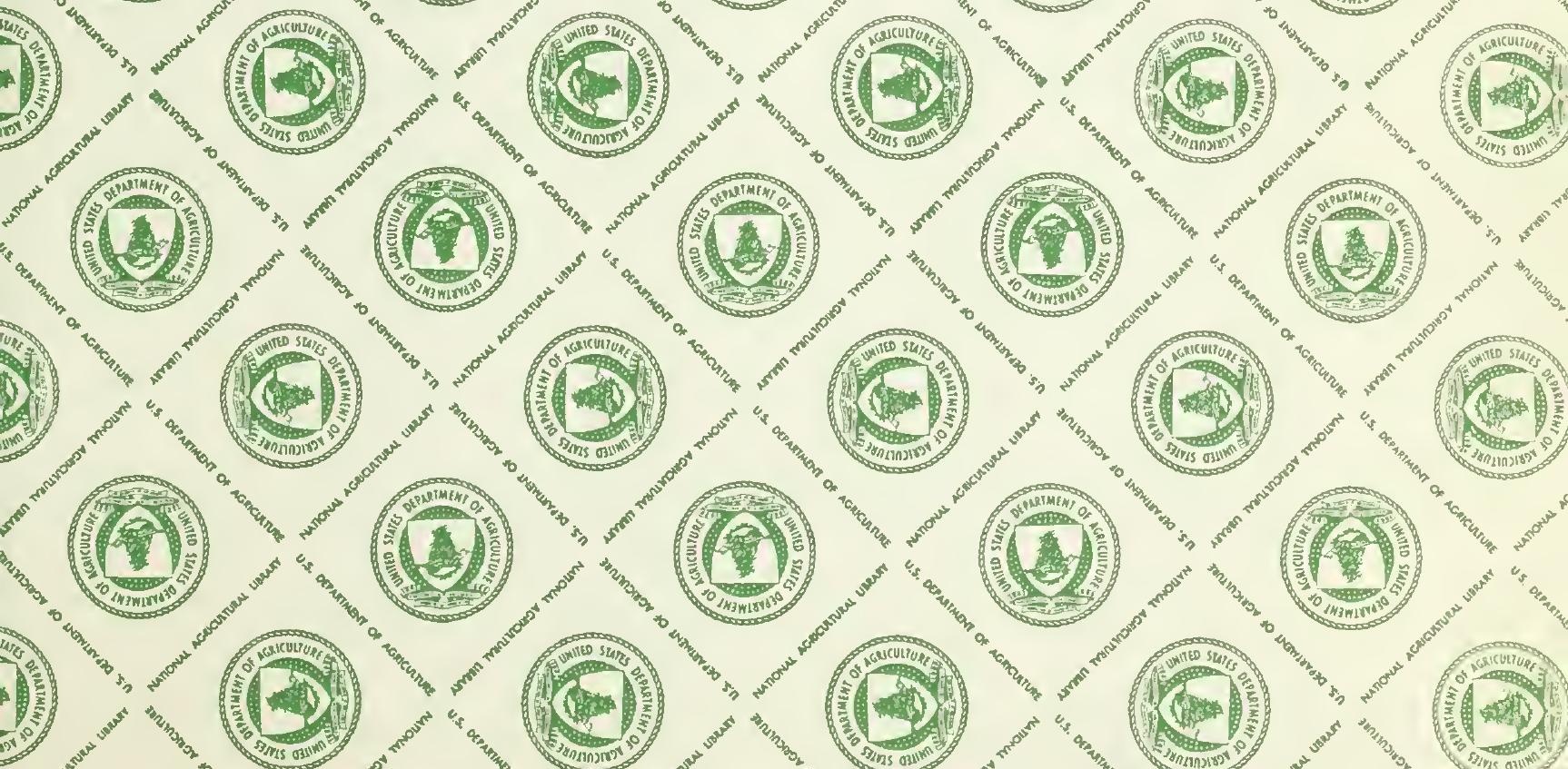





1.962222 C3T222

\title{
MAKING FARM WOODLAND IMPROVEMENT PAY
}

\author{
$B Y$ \\ J. F. HOSNER
}

R. D. $L A N E$
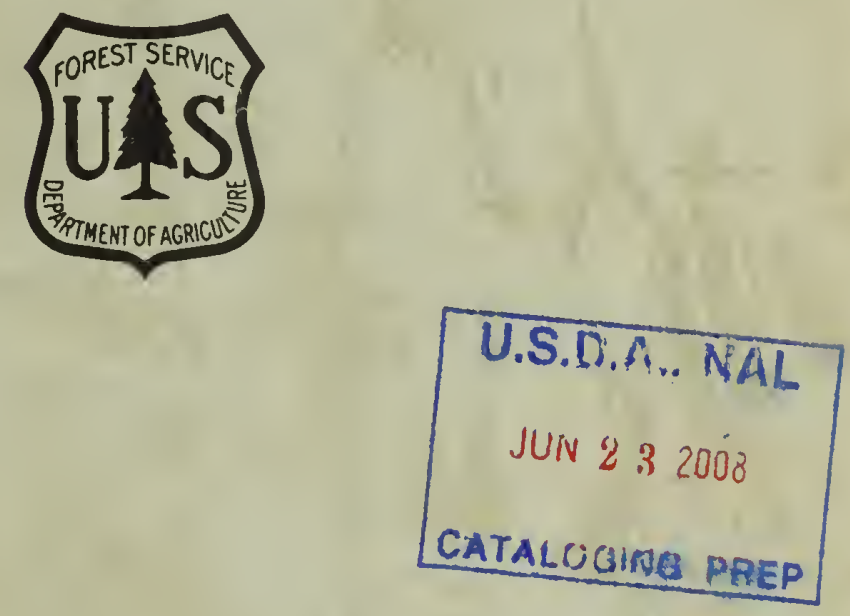

\section{EnTRAL STATES FOREST EXPERIMENT STATION Columbuz 13, 12 hía} PHILIP A. BRIEGLEB, DIRECTOR

\author{
IN COOPERATION WITH THE \\ AGRICULTURE DEPARTMENT \\ SOUTHERN ILLINOIS UNIVERSITY
}


This report is from the

Division of Forest Management

CENTRAL STATES FOREST EXPERIMENT STATION

and from the

Agriculture Department

SOUTHERN ILLINOIS UNIVERSITY

\section{ACKNOWLEDGMENTS}

First results obtained from two farm woodland management demonstrations on the Kaskaskia Experimental Forest of the U. S. Forest Service are reported here. The demonstrations are being carried on in cooperation with the Agriculture Department of Southern Illinois University.

The authors wish to express their appreciation to Southern Illinols University for making funds and facilo ities available, to members of the Agriculture Department of the University for their many helpful suggestions in preparing this report, and to Arthur G. Chapman and Robert K. Winters of the Central States Forest Experiment Station for their assistance in conducting the work and preparing the report. Special recognition is given Leon S. Minckler of the Station for preparing the woodland management plans and to Donald L. Fassnacht, former superintendent of the Kaskaskia Experimental Forest, who supervised the field work and kept the records. 
Introduction ...................... 1

Description of the demonstration areas ......... 2 Initial treatment. .............. 6

Costs and returns............... 7

Prospects for future profits ............. 10 Summary. . . . . . . . . . . . . . 11 Literoture cited ............... 12 


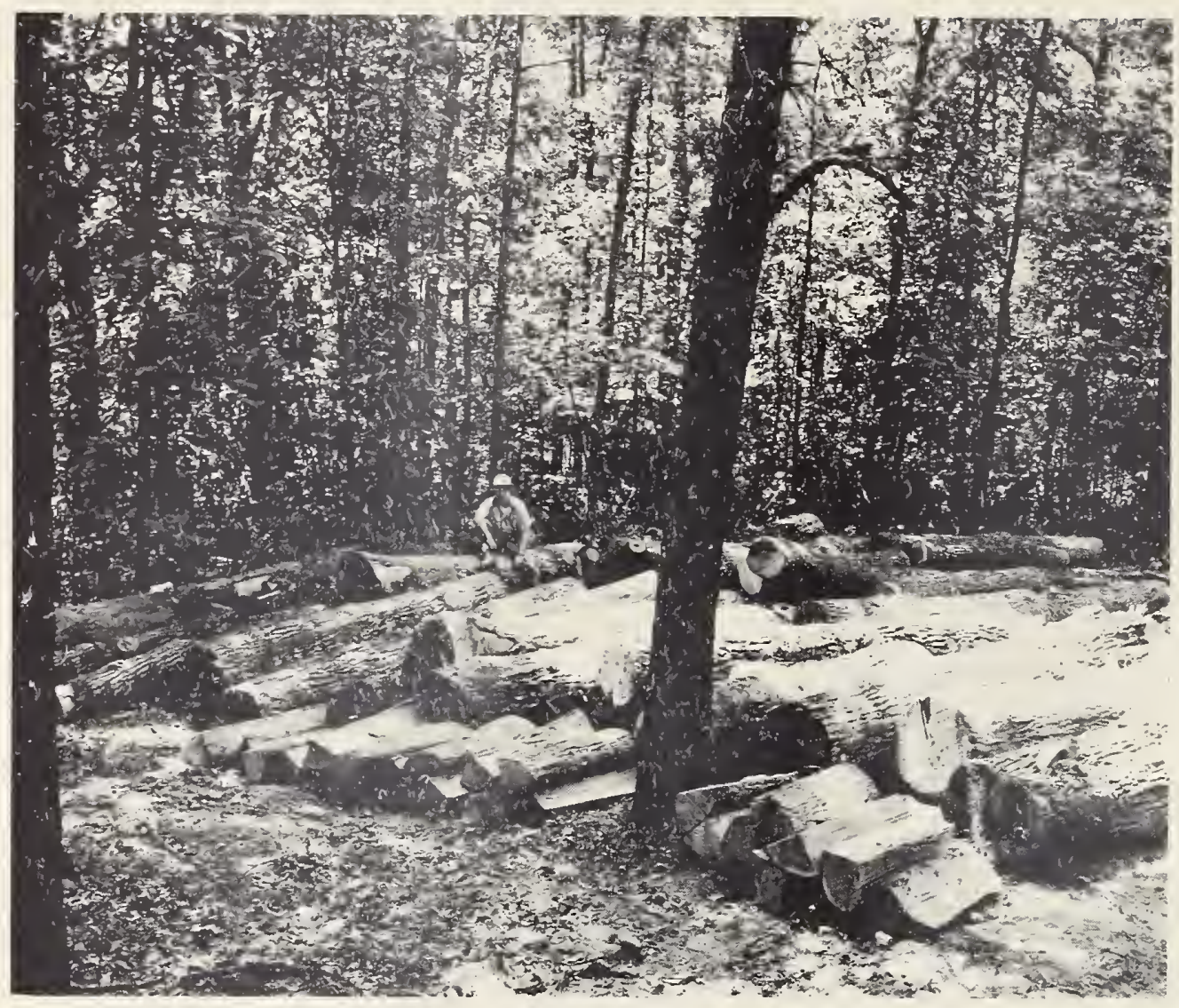

Frontispiece.--The first cut made on the "good" farm woodland yielded 4,420 board-feet of sawlogs, 26.5 chord-feet of stave bolts, and (not shown) 480 linear feet of mine props. This is the approximate annual growth on the 24-acre woodland. 
By

\author{
John F. Hosner// and Richard D. Lane 2/
}

\title{
INTRODUCTION
}

The small woodland owner commonly objects to practicing good forest management on the grounds that "It costs too much to get started" or "I haven "t got the time or money to invest in it." To help solve this perennial economic problem of small forest management, the Carbondale Research Center of the Central States Forest Experiment Station set up two farm woodland demonstration areas on its Kaskaskia Experimental Forest in Illinois. The demonstrations are intended to show how farm labor can be used for woods work during slack seasons and to show that producing timber can add to the farm income. This report gives the financial results of the first three years" operation.

Farm woodland management is especially important in the Central Region because so much of the forest land is owned by farmers. In fact, in southern Illinois and vicinity, three-fourths of the forest area is in such small woodlands. So continued timber production in the region depends greatly upon the small forest.

Failure to adequately protect and manage these woodlands has reduced their contribution to the local economy. For example, in the southern 16 counties of Illinois, farm forests are contributing less than 2 percent to the total farm income (2). 3 However, the forests and forest-products industries are still making a significant contribution to the region. In 1951, railroad shipments of lumber and forest products from southern Illinois ranked 5th out of 10 commodity groups reported in the Southern Illinois Business Newsletter $(\underline{6})$.

Very little forest improvernent work is being done in privately owned woodlands. This is because few farmers or other private owners in the upland region realize that their forests, if given proper protection and management, will yield a continuous crop and financial return. Yet Jo Nelson Spaeth, University of Illinois, states that under proper management the present growth of upland timber in southern Illinois could be increased from 2-1/2 to 3 times with a corresponding increase in yearly income to the owner ( 7 ).

University.

$$
1 \text { Instructor, Agriculture Department, Southern Illinois }
$$

2 Forester-in-Charge, Carbondale Research Center, Central

States Forest Experiment Station.

3) Numbers in parentheses refer to Literature Cited, po 12. 
The farmer's income could be increased still more if he harvested his own woodland crops during slack seasons. Harvesting and delivery costs make up 75 percent of the value of forest products delivered to the buyer, leaving only 25 percent for stumpage returns to the owner (4). Thus, the farmer who does his own woods work could get as much as four times the income from his woodland that he would get if he merely sold the stumpage.

The first problem in obtaining better farm woodland management is one of education. Several state and federal programs are directed toward this end. These include (a) technical assistance to woodland owners as provided by the Cooperative Forest Management Act of 1950, (b) educational programs conducted by State extension foresters, and (c) research and demonstrations in improved woodland management. This report fits into the last category.

\section{DESCRIPTION OF THE DEMONSTRATION AREAS}

The two demonstration areas involved in this project are designated as "good" and "poor" farm woodland. Each is a little more than 20 acres in area. The topography is too rough and steep for farming.

\section{The Good Farm Woodland}

The good farm woodland (fig. l) is located on a better-thanaverage forest site and consists of a fairly good stand of mixed oaks with some hickories and a few yellow-poplars. About two-thirds of the tract was cut over for railroad ties during 1925-1926 and half of it was burned over in 1925. Since then there have been no fires or grazing and until 1949 practicaliy no cutting. In 1949 a complete cruise was made of all, trees 4.5 inches dob.h.4 and larger (table 1). Merchantable trees 5 larger than 10 inches d.b.h. contained approximately 3,700 board-feet gross, International 1/4-inch scale, per acre.

\section{The Poor Farm Woodland}

The poor woodland (fig. 2) consists of a much poorer forest stand growing on an average upland site. Red, black, and white oaks predominate, making up almost three-fourths of the total basal area.6 This tract had been cut, grazed, and burned repeatedly until recent years. Small areas were nearly cleared as a result of this treatment. Recently, some hardwood reproduct.ion and pioneer

4) Diameter at breast height, i.e. 4.5 feet above ground.

5/ Trees containing marketable products in contrast to cull

trees that contain only firewood.

6) The cross-sectional area at breast height of a single tree or of all the trees in a stand, expressed in square feet. 


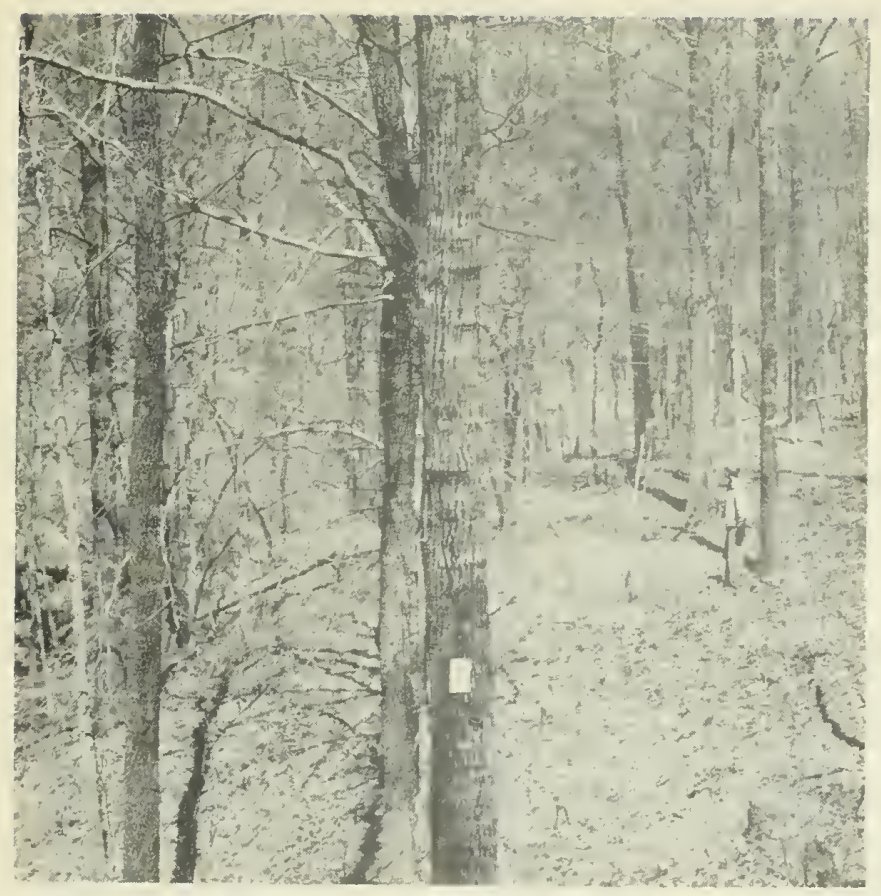
Figure 1.--The "good" woodland is well- stocked with poles but has too few sawtimber trees.

Figure 2.--The "poor" woodland is not adequately stocked with either pole or sawtimber trees.

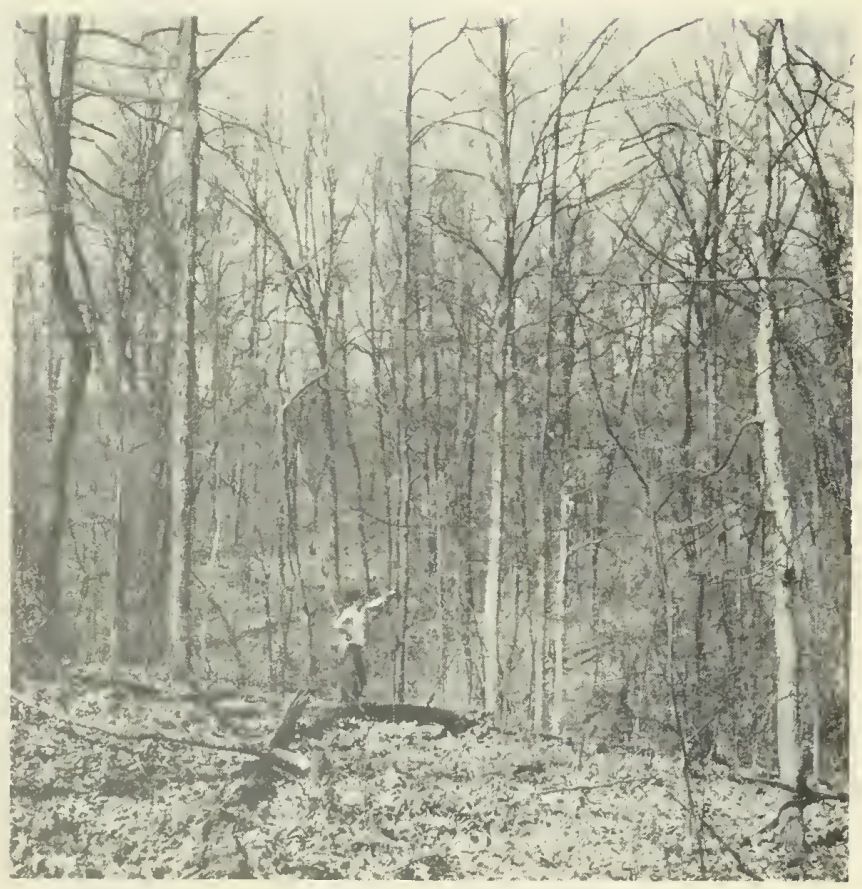


species such as sumac, persimmon, and sassafras have come into these openings.

In 1951, the average acre in this woodland contained the stand shown in table 1. Trees more than 10 inches d.b.h. contained approximately 2,600 board-feet gross per acre.

Table 1.--Original stocking per acre for both stands

GOOD WOODLAND

\begin{tabular}{|c|c|c|c|c|c|c|c|}
\hline \multirow[b]{2}{*}{ Species } & \multicolumn{4}{|c|}{ Number of trees } & \multicolumn{3}{|c|}{ :Basal area (sq. ft.) } \\
\hline & : Poles & $\begin{array}{l}\text { : Saw- } \\
\text { :timber }\end{array}$ & Culls & $:$ : 10 & $\begin{array}{l}\text { Merch : } \\
: \text { trees: }\end{array}$ & : Culls: & Total \\
\hline White oak & 50.7 & 11.6 & 2.9 & 65.2 & 24.4 & 1.3 & 25.7 \\
\hline Black \& red oaks & 18.7 & 16.1 & 25.5 & 60.3 & 25.2 & 1.9 & 27.1 \\
\hline Post oak & 1.5 & .2 & 0 & 1.7 & .7 & 0 & .7 \\
\hline Hickory & 12.3 & 3.9 & 1.4 & 17.6 & 7.9 & .6 & 8.5 \\
\hline Yellow-popl ar & .5 & .7 & $(2 /)$ & 1.2 & 1.2 & .1 & 1.3 \\
\hline Walnut & 1.6 & .6 & .1 & 2.3 & .9 & $(2 /)$ & .9 \\
\hline Miscellaneous & 22.6 & 7.2 & 9.2 & 39.0 & 13.5 & 2.7 & 16.2 \\
\hline Total & 107.9 & 40.3 & 39.1 & 187.3 & 73.8 & 6.6 & 80.4 \\
\hline
\end{tabular}

POOR WOODLAND

\begin{tabular}{lrrrrrrr}
\hline White oak & 16.5 & 6.4 & 2.9 & 25.8 & 10.4 & 1.1 & 11.5 \\
Black \& red oaks & 7.0 & 16.5 & 4.0 & 27.5 & 21.3 & 2.8 & 24.1 \\
Hickory & 13.0 & 3.4 & 3.1 & 19.5 & 7.7 & 1.9 & 9.6 \\
Yellow-poplar & .3 & .2 & $(2 /)$ & .5 & .3 & 0 & .3 \\
Walnut & .5 & .1 & .2 & .8 & .2 & .1 & .3 \\
Miscellaneousl/ & 10.7 & 1.8 & 9.2 & 21.7 & 4.5 & 2.5 & 7.0 \\
\cline { 2 - 7 }$\quad$ Total & 48.0 & 28.4 & 19.4 & 95.8 & 44.4 & 8.4 & 52.8 \\
\hline
\end{tabular}

hardwoods.

I) Includes blackgum, hard maple, beech, elm, and other 2) Less than 0.5 


\section{Actual vs. Optimum Stocking}

The Illinois Technical Forestry Association has recommended practices for the optimum growth of hardwood forests in the State (3). Their recommendations include stocking guides for the number of trees, basal area, and volume per acre. Comparing these guides with actual stocking on the two woodlands shows the following (fig. 3): The good woodland (a) had more than enough poles, (b) had too few sawtimber trees, (c) contained only three-fourths of the recommended basal area, and (d) contained about half the recommended sawtimber volume.

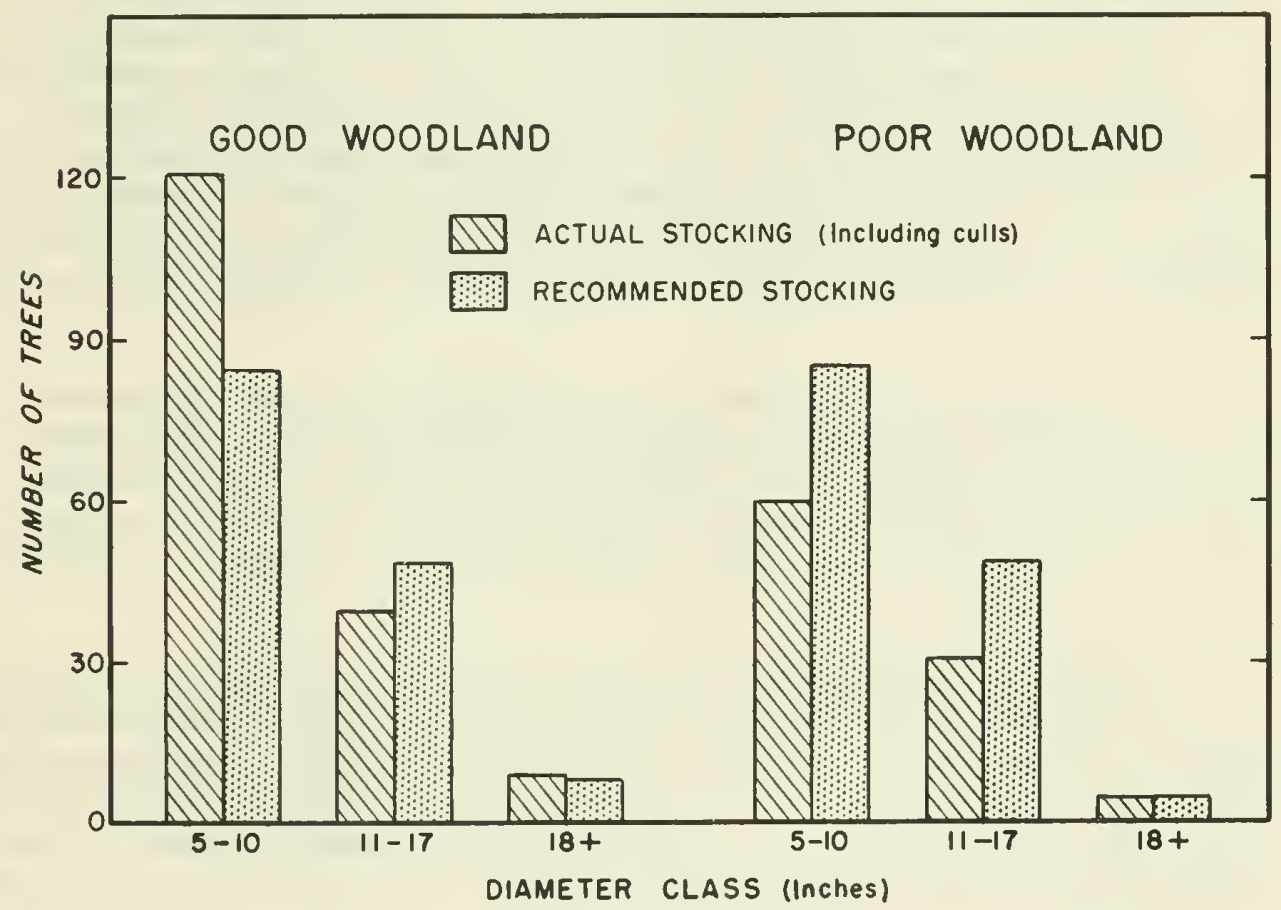

Figure 3.--Actual stocking compared with that recommended by the Illinois Technical Forestry Association.

The poor woodland was (a) understocked in all size classes, (b) had only 35 percent of the recommended basal area, and (c) had only 40 percent of the recommended optimum sawtimber volume. Moreover, approximately half the merchantable trees were over-mature, poorly formed, or for other reasons not considered to be growing stock. 


\section{INITIAL TREATMENT}

The forest practices being applied are intended, first, to rehabilitate the stands and, second, to obtain the maximum continuous production of forest crops while maintaining adequate stocking, quality growth, and frequent harvest. Sustained production at a high level will offer the greatest employment and income opportunities.

Because of wide differences in site, growth, and composition between the two woodlands, the initial treatments used were not the same. The good woodland was fairly well stocked prior to initiating management and was growing approximately 175 board-feet gross per acre per year. Local commercial loggers consider 500 board-feet per acre to be the minimum volume that can be harvested economically. So in order to make an annual harvest in this woodland without cutting more than the growth and at the same time provide for this minimum cut, the tract was divided into three blocks. Annual growth for the entire tract (approximately 4,100 board-feet gross) was cut from one of the three blocks in 1949, another in 1950, and the third in 1951.

Conditions on the poor farm woodland, with its estimated growth of only 75 board-feet gross per acre per year, were such that annual cuts could not be made economically from the start. So the entire block was treated at once, in 1951. However, the long term plan calls for short-interval cuts, the same as for the good farm woodland.

The primary management objective was to completely rehabilitate the stands in the shortest possible time and at the least cost. To meet this immediate objective the first treatment was a combined harvest and improvement operation that removed all trees 4.5 inches d.b.h. and larger that were not selected for growing stock. The merchantable sawtimber trees were cut and sold; the culls and other non-merchantable trees were girdled.

This treatment reduced the average basal area per acre on the good woodland from about 80 square feet to less than 65 . The residual basal area was approximately 35 square feet below that considered desirable ( $\underline{3})$.

The first harvesting and improvement operation reduced the basal area of the poor woodland from 53 square feet per acre to less than 30 square feet per acre, leaving approximately one-third of the estimated optimum ( $(\underline{3})$. Seedlings of shortleaf pine and redcedar were planted in some of the larger openings created in the poor woodland by the cutting and improvement operation. 
All sawlogs harvested were graded according to the Forest Products Laboratory $\log$ grades (1). Those cut on the good farm woodland were 25 percent $\log$ grade 1,25 percent grade 2 , and 50 percent grade 3 . On the poor farm woodland, 20 percent of the logs were grade 1, 20 percent were grade 2, and 60 percent grade 3 . In both woodlands at least twice as much grade 3 material was removed as either grade 1 or grade 2, indicating that the trees cut during the first cycle were mostly of low quality and were the least desirable for future growing stock.

\section{COSTS AND RETURNS}

The total volume harvested on the good woodland during the first three years of management was $12,62 \mathrm{C}$ board-feet net of savlogs and veneer logs, 26.5 chord-feet 7 of wite oak stave bolts, and 720 linear feet of mine props (table 2). The value of these products at roadside was $\$ 331.17$. The harvest cut required a total of 245 man-hours, averaging approximately 10 man-days per year. Using local vage rates for similar vork, this labor vould have an average annual value of $\$ 69.23$. Equipment operation costs for the entire harvesting job viere $\$ 45.20$ which together with the cost of supplies made a total necessary cash outlay for logging of $\$ 49.54$ (table 3 ). In addition, it cost $\$ 18.90$ to girdle the undesirable trees. Therefore, the total cost of the harvesting ant improving operation including labor vas $\$ 276.87$, leaving a return of $\$ 54.30$.

The combined harvest-improvement cut on the poor farm wood1 and produced 22,170 board-feet net of sawlogs and veneer logs, having a local value of $\$ 541.92$. Harvesting these materials required 245 man-hours of labor (table 3). In addition 59 man-hours were spent girdling the undesirable trees and 20 man-hours were required for planting and releasing seedlings. The actual cash outlay for supplies and equipment use totaled $\$ 80.82$. The entire cost--!abor, equipment use, supplies, and planting stock--for rehabilitating the poor farm woodland was $\$ 366.08$. So the job yielded $\$ 175.84$.

The operating returns mentioned above for both woodlands are not all profit because fixed costs such as taxes, interest, and protection have not been deducted. Exact figures for these costs are not available, but they would be the same regardless of how the owner managed his woodland or how much income he got from the timber.

7) A split bolt that measures 12 inches between the two split sides just inside the bark contains one chord-foot. 


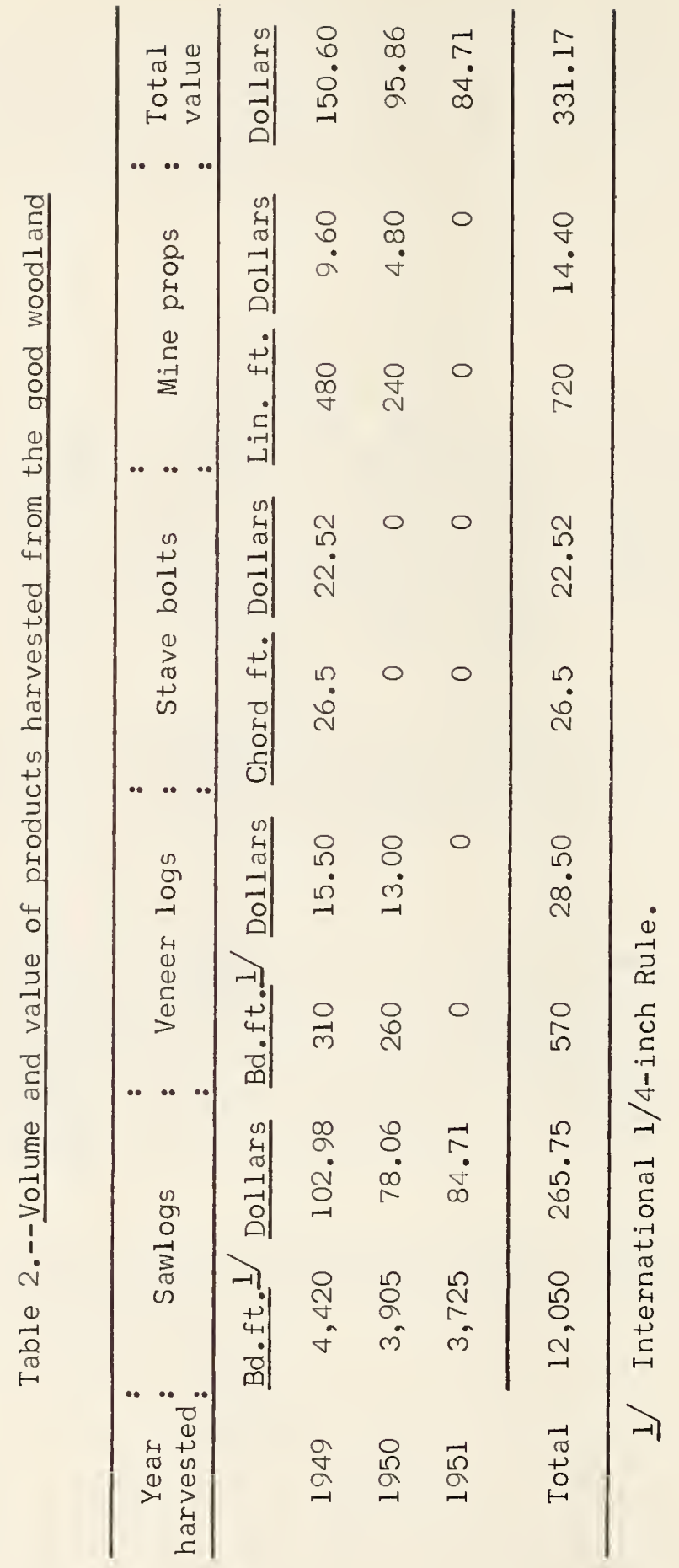


The two farm woodlands have not been managed long enough to predict potential returns from similar small forests. or to show trends in either volume or value resulting from management. However, the results do offer some insight into the financial aspects of rehabilitating neglected woodiands.

The most significant result of the first phase of managing the two woodlands is that the harvest-improvement cut paid for itself and left a small residual for the owner. Moreover, if this had been an ordinary farm situation where the woodland ovner wished to do his own woods work, rather than sell stumpage, his cash return from the poor woodland would heve been $\$ 461.10$ instead of $\$ 175.84$. Or, for every hour spent harvesting, girdling, planting, and releasing planted trees, the ovner would have received $\$ 1.42$ including stumpage. The comparable hourly return from the good voodland was $\$ 1.07$.

Table 3.--Harvesting and rehabilitation time and costs

GOOD WOODLAND

\begin{tabular}{|c|c|c|c|c|c|c|}
\hline \multirow[t]{2}{*}{$\begin{array}{c}\mathrm{Class} \text { of } \\
\text { work }\end{array}$} & \multicolumn{2}{|c|}{ Labor } & \multicolumn{2}{|c|}{ Equipment1/ } & $\begin{array}{l}: \\
: \text { Supplies } 2 / \\
\end{array}$ & \multirow{2}{*}{$\begin{array}{c}\text { Total } \\
\text { Dollars }\end{array}$} \\
\hline & Hours & Dollars & Hours & Dollars & Doilars & \\
\hline $\begin{array}{l}\text { Felling } \\
\text { Skidding } \\
\text { Girdling }\end{array}$ & $\begin{array}{r}168 \\
77 \\
24\end{array}$ & $\begin{array}{r}140.40 \\
68.03 \\
18.90\end{array}$ & $\begin{array}{l}13 \\
15 \\
--\end{array}$ & $\begin{array}{c}13.00 \\
32.20 \\
.-\end{array}$ & $\begin{array}{l}3.22 \\
1.12 \\
-.-\end{array}$ & $\begin{array}{r}156.62 \\
101.35 \\
18.90\end{array}$ \\
\hline Total & 269 & 227.33 & 28 & 45.20 & 4.34 & 276.87 \\
\hline
\end{tabular}

POOR WOODLAND

\begin{tabular}{rrrrrrr}
\hline Felling & 165 & 146.11 & 22 & 22.00 & 5.54 & 173.65 \\
Skidding & 80 & 72.00 & 14 & 37.75 & 6.65 & 116.40 \\
Girdling & 59 & 50.15 & -- & -- & -- & 50.15 \\
Planting & 20 & 17.00 & -- & -- & 8.88 & 25.88 \\
\cline { 2 - 7 } \multicolumn{1}{r}{ Total } & 324 & 285.26 & 36 & $5 . .75$ & 21.07 & 366.08 \\
\hline
\end{tabular}

If Pover saw, craviler tractor, and rubber-tired sulky. Hand tools and plarting stock. 


\section{PROSPECTS FOR FUTURE PROFITS}

Receipts from the poor voodland, after deducting all rehabilitation costs, were more than three times those obtained from the good woodlend. This difference is due almost entirely to improved logging equipment and better trained crews. The costs reported for the good woodland are the averages of three years and include some of the first logging done at the experimental forest. Those for the poor woodland were incurred after three years of experience. Thus, the costs were higher for the good woodland than they would have been if the harvesting had been done with present equipment and trained crews. The first block of the good woodland was cut in 1949. Approximately the same volume was cut in the same block again in 1952 at about half the cost. The private woodland owner who harvests his own forest crops will probably experience similar improvements in logging "know-how" during the first few years.

A larger volume per acre was cut in the poor than in the good woodland. Also, more skid trails and $\log$ decks were necessary in the good than in the poor vioolland. Both of these differences favor lower rehabilitation costs on the poor woodland. Even though the rehabilitation costs vere lower and the residual after deducting such costs vias higher on the poor wooland, another harvest will not be available on this tract for several years. The current annual harvest is expected to be sustained for the next several years on the good woodland. As soon as stocking reaches the optimum, the harvest will be increased.

With few exceptions, farm woolland ovners of the Central States do not have the heavy mechanical logging equipment used in these demonstrations. However, wheel-type farm tractors, log chains, hand cross-cut saws, and similar tools are common farm equipment. These farm tools could be used to fell, buck, and skid the woodland products. Such equipment is much cheaper to buy and operate than standard logging equipment. Furthermore, most of the retirement costs for these farm implements would be charged to ordinary farm work. So with some experience and training the owner probably could harvest his woodland products at lovier costs than those reported here. In addition, it is possible that the owner could harvest economically a smaller volume per acre than the 500 board-feet considered to be the minimum for commercial operations.

As the general condition of the stands improve, more time will be spent in harvesting the higher quality timber and less time in girdling and other improvement work. And of course income will increase with growth and quality. According to Ralph A. Read (ㅍ), timber stand improvement work done 15 years ago has tripled the basal area of desirable stems in the understory of hardwoods in the Ozark National Forest of north Arkansas. Growth following the first 
cut and improvement treatment for the good farm woodland seems to be following this pattern. The block cut in 1949 was cut again in 1952. During the 3-year interval between the first and second cut, the first block grew 257 board-feet per acre per year net as compared with the estimated 175 board-feet before treatment.

\section{SUMMARY}

Two farm woodland demonstration areas set up on the Kaskaskia Experimental Forest in southern Illinois showed a small cash return on the first improvement cut. These two blocks of mixed oak and hardwood timber were put under management during the period 1949. 1951. One was designated as "good" woodiand and contained a volume of 3,700 board-feet; the other, called "poor" voodland, had only 2,600 board-feet.

The first job in converting these siands to managed forests was to harvest the poorest merchantabie trees and to girdle the culls, poorly formed trees, and inferior species.

The good woodland was divided into three biocks; total annual growth (about 4,100 board-feet) was cut from one block each year. The poor woodland couid not support an annual cut from the start, so work on this stand was delaved until 1951 when the whole stand was given an improvement cut at once. In addition, some planting was done in the openings of this stand.

Both stands showed a net return after ail expenses for labor, equipment, and supplies were paid. Ihis indicates that the owner of a small, neglected woodland can give his stand a good start toward maximum productivity and make money while doing it. 


\section{LITERATURE CITED}

(1) Forest Products Laboratory.

1949. Hardwood lumber log grades for standard lumber and how to apply them. U. S. Forest Prod. Lab. Release D1737-A. 16 pp., illus.

(2) Hutchison, O. Keith, and Winters, Robert $\mathrm{K}$.

1951. Marketing the farm forest products of southern

Illinois. Central States Forest Expt. Sta. Tech. Paper 123. 39 pp., illus.

(3) Illinois Technical Forestry Association.

1950. Recommended forest practices for Illinois hardwood timber types. $17 \mathrm{pp}$.

(4) Preston, J. F.

1949. Farm wood crops. 301 pp., illus. New York.

(5) Read, Ralph A.

1951. Timber stand improvement benefits Ozark hardwoods.

Southern Forest Expt. Sta. Forestry Note 73.4 pp.

(6) Southern Illinois University.

1952. Business Newsletter (February):14-15.

(7) Spaeth, J. Nelson.

1948. Forests of southern Illinois. Southern Illinois.

Booklet No. 4. 17 pp., illus. Joint Committee on Southern Illinois, Univ. of Illinois. 
TERRITORY SERVED BY THE

CENTRAL STATES FOREST EXPERIMENT STATION FOREST SERVICE

U. S. DEPARTMENT OF AGRICULTURE

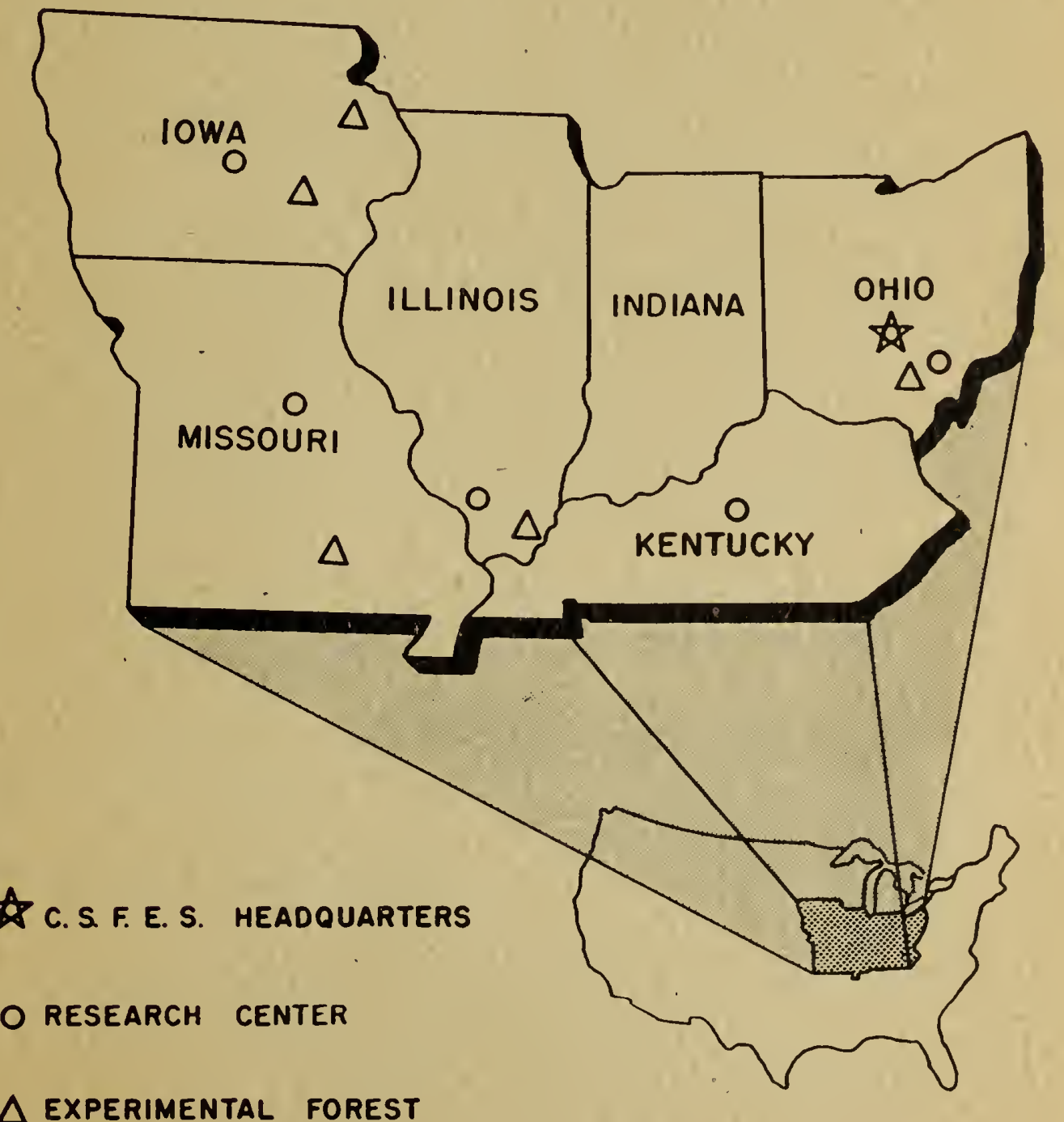


NATIONAL AGRICULTURAL LEAR

1022500916 